\title{
Efek Perbedaan Komposisi Konsentrat terhadap Perbaikan Nilai Nutrisi Jerami Padi
}

\author{
S. D. Widyawati \\ Program Studi Peternakan, Fakultas Pertanian Universitas Sebelas Maret, \\ Jl. Ir. Sutami 36 A Surakarta 657126
}

\begin{abstract}
ABSTRAK
Penelitian bertujuan untuk mengevaluasi nilai nutrisi jerami padi sebagai pakan basal yang diberikan tambahan pakan penguat dengan perbedaan pakan sumber proteinnya (bungkil kedelai terproteksi, BKT dan tepng daun lamtoro, DL). Perlakuan yang diterapkan sebanyak 3 perlakuan, P0 : $100 \%$ jerami padi (JP), P1 : P0 + pakan penguat-1 (BK-DK); P2 : P0 + pakan penguat-2 (DLDK). Data dianalisis dengan analisis variansi dalam Rancangan Acak Lengkap pola searah dengan 3perlakuan dan 3 ulangan. Hasil penelitian menunjukkan bahwa pemberian pakan penguat dalam pakan basal JP nyata $(\mathrm{P}<0.05)$ meningkatkan konsumsi ransum, berturut-turut sebesar 3,85, 4,60 dan 4,95kg/ekor/hari.. Kecernaan BK berturut-turut untuk P0, P1 dan P2 sebesar 44,64, 55,09 dan 49,50 persen. Kecernaan BO Masing-masing sebesar 45,91, 56,19 dan 50,67 persen. Sedangkan kecernaan PK sebesar 44.78, 71,88 dan 61,33 persen dan kecernaan SK sebesar 78,92, 74,51 dan 74,82. Nilai kecernaan nutrien ini menunjukkan adanya perbaikan sistem biofermentasi mikrobia dalam rumen sehingga memungkinkan terjadinya peningkatan sintesis mikrobia rumen dan kecernaan nutrien menjadi meningkat. Kesimpulan yang dapat diambil bahwa. kualitas ransum berbasis jerami padi dapat diperbaiki dengan pemberian konsentrat. Kecernaan nutrien memberikan nilai yang lebih baik pada penambahan konsentrat yang mengandung bungkil kedelai dibandingkan daun lamtoro.
\end{abstract}

Kata kunci : konsentrat, sapi PO, performan, kecernaan

\section{The Effect of Different Concentrate Composition on Nutritive Value of Rice Straw}

\section{ABSTRACT}

Since rice straw is seasonal and low quality roughage, thus, a supplementation for it is needed. Lamtoro leaf meal (LLM) and soybean meal (SBM), have both soluble and bypass protein, so it enough potential to supply nutrients to optimize of rumen microbes and improve animal performance. Supplementation with LLM or SBM significantly increased dry matter, organic matter, crude protein and crude fiber intake $(P<0.05)$. This fact showed that LLM or SBM supplementation made an improvement of rumen fermentation by microbes. Comparison between LLM and SBM to basal diet clearly showed that basal diet was the lowest $(P<0.05)$ nutrient intake and nutrient digestibility, however, the animal fed basal diet degraded crude fiber was not affected. It has been shown that supplementation with lamtoro leaf meal or soybean meal were palatable, fermentable and reasonably digestible. Therefore, the use of these feedstuffs as supplement to rice straw are strongly recommended.

Key words : concentrate, PO beef cattle, performance, digestibility 


\section{PENDAHULUAN}

Pola pemeliharaan peternakan rakyat, secara umum masih mengandalkan pakan hijauan berupa jerami padi. Ini kemungkinan disebabkan karena rendahnya daya beli konsentrat. Harga konsentrat yang dirasa masih terlalu mahal, sehingga pakan penguat yang digunakan hanya berupa dedak padi atau ampas tahu yang masih mungkin tersedia di sekitar lokasi pemeliharaan.

Jerami padi merupakan limbah pertanian yang sangat potensial sebagai sumber pakan serat bagi ternak ruminansia. Namun ketersediaannya sangat tergantung pada musim. Serat yang terkandung didalamnya terdiri atas selulosa yang telah mengalami lignifikasi lanjut dan telah terjadi kristalisasi dengan kadar silika yang cukup tinggi, sehingga nilai nutrisinya sangat jelek. Formula pakan seperti ini tentunya tidak bisa diharapkan bahwa ternak akan tumbuh secara baik dan optimal. Kendala lain yang dijumpai pada peternakan rakyat bahwa pola pikir yang sederhana dan apa adanya, penjualan ternak dilakukan pada saat membutuhkan dana dan daya beli konsentrat sangat rendah. Sebagaimana yang dinyatakan oleh Direktorat Budidaya Peternakan (2004) bahwa masalah umum pengembangan peternakan di Indonesia adalah sistim dan usaha budidaya peternakan kurang berorientasi kepada pasar dan profit, terkait dengan usaha sambilan, skala ekonomi dan orientasi produksi.

Dari berbagai kendala yang ada, maka penelitian ini didesain untuk memperbaiki kualitas pakan jerami padi dengan meningkatkan efisiensi penggunaan pakan kualitas rendah melalui pemberian pakan penguat berupa bungkil kedelai dan daun lamtoro sebagai pakan sumber protein dan urea serta molases dengan rasio yang berbeda.

Bungkil kedelai telah terbukti mempunyai nilai nutrisi yang sangat baik. Pakan ini termasuk kelas bahan pakan sumber protein dengan kandungan proteinnya sebesar
48\%. Proteksi bahan pakan ini dengan pemanasan $100 \mathrm{oC}$ selama 1 jam (Widyobroto, et al., 1999) mampu meningkatkan protein yang bersifat bypass dalam rumen. Sebagai salah satu komponen ransum akan berakibat pada kenaikan nilai ekonomi walaupun mempunyai aspek nutrisi yang sangat baik.

Lamtoro merupakan leguminosa pohon yang digunakan sebagai tanaman pagar atau penghijauan di perkotaan.Daun lamtoro mempunyai nilai nutrisi yang cukup baik. Kandungan nutrien bahan pakan ini terdiri atas PK 23\% dan TDN 60\%. Sutardi (1993) menyatakan bahwa daun lamtoro mengandung protein yang bersifat bypass selain protein yang soluble. Sehingga diharapkan selain mampu menumbuh kembangkan mikrobia rumen juga mampu menyumbangkan protein pasca rumen.

Pemenuhan kebutuhan protein bagi ternak ruminansia berasal dari protein mikrobia rumen yang mampu mencukupi sekitar 60 $80 \%$ (Johnson, 1978) dari total kebutuhan protein dan protein pakan yang lolos dari degradasi rumen (bypass protein). Peningkatan sintesis protein mikrobia telah diupayakan melalui pemberian urea dan molases dan bypass protein dipenuhi dari bungkil kedelai dan daun lamtoro.

Penelitian ini diharapkan mampu menjawab permasalahan yang dihadapi peternak rakyat bahwa penambahan pakan penguat berupa konsentrat yang terdiri atas bahan pakan sumber protein bypass dan soluble (bungkil kedelai dan daun lamtoro) serta urea dan molases untuk sintesis mikrobia rumen dapat memperbaiki kualitas jerami padi melalui peningkatan nilai kecernaannya,

\section{MATERI DAN METODE}

Percobaan ini telah dilakukan di Kandang Sapi milik Peternak di desa Gentan, Bekonang Kabupaten Sukoharjo menggunakan sapi PO jantan sebanyak 9 ekor. Sapi dibagi ke dalam 3 perlakuan ransum, setiap perlakuan diulang 3 kali. Analisis bahan percobaan 
Tabel 1. Komposisi dan kandungan nutrien pakan penguat (PP)

\begin{tabular}{lcccccc}
\hline \hline \multicolumn{1}{c}{ Konsentrat } & $\begin{array}{c}\text { Bahan } \\
\text { kering }\end{array}$ & $\begin{array}{c}\text { Protein } \\
\text { kasar }\end{array}$ & $\begin{array}{c}\text { Lemak } \\
\text { kasar }\end{array}$ & $\begin{array}{c}\text { Serat } \\
\text { kasar }\end{array}$ & Abu & TDN $\left.^{* *}\right)$ \\
\hline Konsentrat-1 & 87,22 & 28,08 & 6,37 & 5,61 & 14,70 & 78,34 \\
Konsentrat-2 & 80,23 & 27,14 & 4,75 & 9,91 & 11,23 & 70,11 \\
Rumput lapang & 94,47 & 12,26 & 2,22 & 16,58 & 11,92 & 61,24 \\
Jerami Padi & 32,79 & 2,19 & 2,36 & 17,06 & 6,50 & 48,54 \\
\hline
\end{tabular}

Keterangan : ${ }^{*}$ estimasi TDN $=59,68-1,08 \mathrm{SK}+0,3136 \mathrm{PK}+1,22 \mathrm{~L}+0,2508 \mathrm{BETN}$ (Sutardi, 1991)

dilakukan di Laboratorium Ilmu Nutrisi dan Makanan Ternak, Jurusan Peternakan Fakultas Pertanian UNS. Analisis kandungan nutrien bahan percobaan dilaksanakan dengan menggunakan analisis proksimat mengikuti pedoman dari AOAC (1980).

Sapi PO jantan sebanyak 9 ekor yang berumur $1-1.5$ tahun dengan rataan bobot badan $150 \mathrm{~kg}$ dibagi secara acak kedalam 3 perlakuan ransum. Masing-masing perlakuan diulang 3 kali dengan satu ekor sapi. Bahan pakan yang digunakan sebagai komponen pakan penguat (PP) diperoleh di Surakarta dan sekitarnya. Ransum basal digunakan jerami padi (JP) sebagai ransum kontrol (P0), P1 disusun dari P0 + bungkil kedelai terproteksi (BKT) dan P2 disusun dari P0 + tepung daun lamtoro (TDL). Adapun formulasi pakan suplemen GPFS disajikan pada Tabel 1.

Ransum sebanyak 3 macam diberikan pada sapi dengan kuantitas pemberian sesuai dengan kebutuhan bahan kering (BK) ternak sebanyak 3\% dari bobot badan. Ransum terdiri atas ransum basal berupa jerami padi dan pakan penguat yang diberikan sebanyak maksimal 20 - $30 \mathrm{gram} / \mathrm{kg}{ }^{0.75}$ (de Young and Bruchem, 1999). Pakan penguat yang diberikan merupakan pakan suplemen yang telah teruji nilai nutrisinya (Widyawati dan Pratitis, 2006).

Komposisi bahan pakan dan kandungan nutrien ransum percobaan yang dikaji nilai nutrisinya secara in vivo, disajikan pada Tabel 2. Evaluasi nilai nutrisi ransum percobaan dilakukan melalui pengamatan terhadap beberapa parameter yang dapat memberikan gambaran kualitas ransum percobaan.
Penentuan nilai kecernaan nutrien yang meliputi kecernaan Bahan kering (BK), bahan organik (BO), protein kasar (PK) dan serat kasar (SK) ransum dilakukan dengan metode koleksi total feses (Tillman et al., 1989). Penentuan nilai kecernaan nutrien ini dilakukan selama 7 - 10 hari dengan periode adaptasi dan pendahuluan selama 14 hari.

Pada tahap koleksi, dilakukan pengukuran terhadap jumlah ransum yang dikonsumsi, sisa ransum, dan ekskresi feses. Sisa ransum dan feses dikoleksi kemudian ditimbang jumlah total sisa dan jumlah total feses, pekerjaan ini dilakukan setiap hari pada jam yang sama. Selanjutnya dilakukan pengambilan sampel setelah dihomogenkan dengan menggunakan mixer (untuk feses) ditimbang dan dikeringkan dibawah sinar matahari. Setelah kering ditimbang lagi untuk mendapatkan berat kering feses, setelah satu minggu dikomposit dan diambil sampel untuk analisis BK, BO, PK dan SK. Analisis nutrien ini juga dikerjakan untuk ransum yang diberikan dan sisa ransum.

\section{HASIL DAN PEMBAHASAN}

\section{Konsumsi Ransum}

Pada dasarnya ternak mengkonsumsi ransum untuk memenuhi kebutuhan energinya, ketika kebutuhan energinya telah terpenuhi maka ternak akan berhenti makan. Erwanto (1995) menjelaskan bahwa apabila ransum tidak padat energi (tinggi serat) maka daya tampung alat pencernaan, terutama organ 
Tabel 2 . Kandungan nutrien ransum percobaan (\%)

\begin{tabular}{lccccc}
\hline \hline Ransum Percobaan & $\begin{array}{c}\text { Protein } \\
\text { kasar }\end{array}$ & Lemak & Serat kasar & Abu & TDN \\
\hline $\mathrm{P}-0$ & 7,34 & 6,61 & 47,91 & 20,05 & 49,81 \\
$\mathrm{P}-1$ & 17,88 & 3,49 & 17,70 & 14,86 & 76,91 \\
$\mathrm{P}-2$ & 17,69 & 3,17 & 18,56 & 14,17 & 75,26 \\
\hline
\end{tabular}

pencernaan fermentatif, akan menjadi faktor pembatas utama konsumsi ransum. Selanjutnya dinyatakan bahwa ternak akan berhenti makan setelah kapasitas rumennya terpenuhi, meskipun sesungguhnya masih memerlukan tambahan energi. Jumlah nutrien yang dikonsumsi oleh sapi dapat dilihat pada Tabel 3. Pemberian pakan konsentrat menunjukkan adanya pengaruh sangat yang nyata $(\mathrm{P}<0,05)$ terhadap jumlah pakan yang dikonsumsi. Sapi yang mendapat perlakuan kontrol (tanpa penambahan pakan konsentrat) memperlihatkan konsumsi ransum yang paling rendah $(3,65$ $\mathrm{kg} / \mathrm{hari}$ ). Sedangkan sapi-sapi yang mendapat tambahan pakan penguat (PP), jumlah ransum yang dikonsumsi nyata lebih tinggi. Sementara pakan penguat dengan komposisi yang berbeda memberikan pengaruh yang nyata terhadap jumlah ransum yang dikonsumsi. Jika dilihat dari komposisi kimia ransum perlakuan, perlakuan kontrol (P0) mengandung nutrien yang sangat rendah karena hanya terdiri atas jerami padi $(90 \%)$ dan rumput lapangan $(10 \%)$. Keadaan ini menunjukkan bahwa banyaknya ransum yang dikonsumsi oleh sapi-sapi yang mendapat pakan hijauan saja secara kuantitas telah terpenuhi sebagaimana ransum perlakuan yang lainnya. Namun dilihat dari kebutuhan nutriennya kemungkinan besar belum terpenuhi karena rendahnya kandungan nutrient jerami padi dan rumput lapangan. Keadaan ini sesuai dengan pendapat Erwanto (1993) di atas bahwa faktor pembatas konsumsi ransum pada P0 lebih ditentukan oleh kapasitas lambung. Pada tingkat konsumsi ransum sebesar $3.65 \mathrm{~kg} / \mathrm{hari}$ kapasitas lambung sapi sudah penuh namun kebutuhan nutrien dan energinya masih berada di bawah kebutuhannya.
Tabel 3 memberikan penjelasan bahwa sapi-sapi yang diberi ransum P2 mengkonsumsi ransum dengan jumlah yang lebih tinggi $(\mathrm{P}<0,05)$ dibandingkan $\mathrm{P} 1$. Hal ini dapat memberikan gambaran bahwa tinggi rendahnya ransum yang dikonsumsi ternak, selain ditentukan oleh kapasitas lambung (secara fisik) juga secara kimiawi ditentukan oleh kualitas pakan. Semakin baik kualitas ransum, maka akan menurunkan jumlah ransum yang dikonsumsi. Sehingga pakan penguat yang mengandung bungkil kedelai mempunyai kualitas yang lebih baik dari daun lamtoro. Penambahan pakan penguat memberikan kontribusi yang nyata terhadap peningkatan kebutuhan nutrien sapi. Konsumsi protein kasar nyata $(\mathrm{P}<0,05)$ oleh perbedaan komposisi pakan penguat yang ditambahkan pada ransum basal jerami padi. Konsumsi P0 terendah $(0,27$ $\mathrm{kg} /$ hari) diikuti P1 (0,66 kg/hari) dan P2 (0,63 $\mathrm{kg} / \mathrm{hari}$ ), keadaan ini menunjukkan jumlah protein yang dikonsumsi ditentukan oleh tinggi rendahnya kandungan protein ransum. Sedangkan konsumsi serat kasar tidak nyata berbeda antar perlakuan, hal ini disebabkan oleh kandungan serat kasar dalam pakan suplemen sangat rendah sehingga peningkatan konsumsi asal pakan penguat tidak memberikan pengaruh yang nyata terhadap peningkatan konsumsi serat kasarnya.

Sebagaiman yang dinyatakan oleh Widyobroto (1993) bahwa perlakuan pemanasan $100^{\circ} \mathrm{C}$ selama 1 jam akan meningkatkan protein yang tahan terhadap degradasi mikrobia dalam rumen namun mempunyai nilai kecernaan intestine yang tinggi. Selain itu protein asal pakan yang dirombak didalam rumen dan digunakan oleh 
Tabel 3. Pengaruh Perlakuan Terhadap Konsumsi Ransum

\begin{tabular}{lllll}
\hline \hline Peubah & & P0 & P1 & P2 \\
\hline Konsumsi BK, kg/hari & $3,65^{\mathrm{c}}$ & $4,60^{\mathrm{b}}$ & $4,95^{\mathrm{a}}$ & \\
Konsumsi BO, kg/hari & $2,92^{\mathrm{b}}$ & $3,98^{\mathrm{a}}$ & $4,62^{\mathrm{a}}$ & \\
Konsumsi PK, kg/hari & $0,27^{\mathrm{c}}$ & $0,66^{\mathrm{a}}$ & & $0,63^{\mathrm{b}}$ \\
Konsumsi SK, kg/hari & $1,75^{\mathrm{a}}$ & $1,86^{\mathrm{a}}$ & $2,01^{\mathrm{a}}$ & \\
\hline
\end{tabular}

Keterangan : Nilai rataan yang bertanda huruf kecil yang berbeda pada baris yang sama menunjukkan adanya perbadaan yang nyata $(\mathrm{P}<0,05)$

Tabel 4. Pengaruh Perlakuan Terhadap Kecernaan Ransum

\begin{tabular}{lllll}
\hline \hline Peubah & P0 & P1 & P2 \\
\hline Kecernaan BK, kg/hari & $44,64^{\mathrm{a}}$ & $55,09^{\mathrm{a}}$ & $49,50^{\mathrm{a}}$ & \\
Kecernaan BO, kg/hari & $45,91^{\mathrm{a}}$ & $56,19^{\mathrm{a}}$ & $50,67^{\mathrm{a}}$ & \\
Kecernaan PK, kg/hari & $44,78^{\mathrm{b}}$ & $71,88^{\mathrm{a}}$ & $61,33^{\mathrm{ab}}$ & \\
Kecernaan SK, kg/hari & $78,92^{\mathrm{a}}$ & $74,51^{\mathrm{a}}$ & $74,82^{\mathrm{a}}$ \\
\hline
\end{tabular}

Keterangan : Nilai rataan yang bertanda huruf kecil yang berbeda pada baris yang sama menunjukkan adanya perbadaan yang nyata $(\mathrm{P}<0,05)$

mikrobia untuk bertumbuh dan berkembang akan menyediakan protein asal mikrobia pada proses pencernaan pasca rumen. Mikrobia dalam rumen merupakan material pakan sumber protein yang bernilai hayati tinggi sebesar $81 \%$ untuk bakteri dan $80 \%$ untuk protozoa (Sutardi, 1978). Selanjutnya dinyatakan bahwa sekitar 1/2 sampai 2/3 N berasal dari mikrobia untuk memenuhi kebutuhan protein bagi induk semangnya (host).

\section{Kecernaan Nutrien Ransum}

Penentuan nilai kecernaan nutrien merupakan salah satu cara untuk melakukan evaluasi nutrisi pakan atau ransum yang diberikan pada ternak. Tinggi rendahnya nilai ini ditentukan oleh beberapa faktor yang dapat mempengaruhinya. Tillman et al., (1989) menyatakan bahwa penyiapan ransum, komposisi pakan dan jumlah ransum yang dikonsumsi serta faktor ternak itu sendiri akan mempengaruhi nilai kecernaan ransum.

Pengukuran kecernaan nutrient ini hanya didasarkan pada jumlah nutrien yang tertinggal dalam tubuh dari jumlah nutrien yang dikonsumsi. Sehingga nilai ini menunjukkan nilai kecernaan semu.(Apparent Digestible Nutrient $=$ ADC). Sementara nilai kecernaan nutrien yang sejati (True Digestible Nutrien = $T D C$ ) dihitung sebagai Retensi Nitrogen untuk proteinnya.

Nilai kecernaan nutrien yang telah diukur dapat dilihat pada Tabel 4. Nilai kecernaan nutrien yang diukur ternyata kecernaan $\mathrm{BK}$ dan $\mathrm{BO}$ dipengaruhi $(\mathrm{P}<0,05)$ oleh penambahan suplemen dalam ransum basal rumput lapangan dan jerami padi. Sedangkan kecernaan PK sangat nyata $(\mathrm{P}<0.01)$ dipengaruhi oleh penambahan pakan suplemen dalam ransum. Keadaan ini menjelaskan bahwa pakan suplemen memberikan pasokan protein yang signifikan terhadap sejumlah protein yang tertinggal didalam tubuh ternak.

Kecernaan BK dan BO pada ransum P0 menunjukkan berbeda tidak nyata dibandingkan antar ransum perlakuan (P0, P1 dan P2) dan perbedaan komposisi pakan penguat tidak memberikan perbedaan pada nilai kecernaan BK dan BO. Kecernaan PK ransum P0 nyata $(\mathrm{P}<0.05)$ lebih rendah dibandingkan ransum perlakuan (P1 dan $\mathrm{P} 2)$ dan perbedaan komposisi pakan penguat tidak memberikan perbedaan pada nilai kecernaan SK. Keadaan ini memberikan petunjuk bahwa penambahan 
pakan penguat menyebabkan perbaikan proses pencernaan dilihat dari peningkatan konsumsi maupun kecernaan nutriennya (BK, BO dan PK). Kecernaan SK tidak dipengaruhi oleh perbedaan komposisi pakan penguat. Hal ini menunjukkan bahwa kandungan SK ransum tidak mempengaruhi nilai kecernaan SK, namun kecernaan nutrien ini lebih ditentukan oleh jumlah SK yang dikonsumsi.

\section{KESIMPULAN}

Pakan penguat yang diberikan pada pakan basal jerami padi mampu memperbaiki nilai kecernaan ransum sapi. Pakan penguat yang disusun dengan bungkil kedelai sebagai pakan sumber protein lebih baik dibandingkan daun lamtoro.

\section{DAFTAR PUSTAKA}

Anonim, 2004. Petunjuk Praktikum Biokimia Nutrisi. Laboratorium Biokimia Nutrisi, Jurusan Nutrisi dan Makanan Ternak. Fakultas Peternakan, UGM. Yogyakarta.

Association of Official Analysis Chemist. 1980. Official methods of analysis of the Association of Official Analytical Chemist. 13th ed. Association of Official Analytical Chemist, Washington, DC.

McDonald, P., R.A. Edward and J.F.D. Greenhalgh. 1988. Animal Nutrition. 4th edition. English Language Book Society, Longman, London.

Ørskov, E.R. 1992. Protein Nutrition in Ruminants. Second edition. Academic Press. London.

Ørskov, E.R., Ojwang, I. and Reid, G.W. 1988. A study on consistency of differences between cows in rumen outflow rate of fibrous particles and other substrates and consequences for digestibility and intake of roughages. Animal production , 47:45-5.

Soejono M., B. P. Widyobroto, R. Utomo dan A. Agus. 1998. Standardisasi Pengukuran
Degradasi In sacco di Indonesia. Laporan Penelitian Hibah Bersaing VII Perguruan Tinggi. Fakultas Peternakan UGM.

Sutardi, T. 1978. Ikhtisar Ruminologi. Dept. Ilmu Makanan Ternak, Fakultas Peternakan IPB. Bogor.

Sutardi, T. 1993. Peningkatan Produksi Ternak Ruminansia Melalui Amoniasi Pakan Serat Bermutu Rendah, Defaunasi dan Suplementasi Sumber Protein Tahan Degradasi Dalam Rumen. Laporan Penelitian Hibah Bersaing. Fakultas Peternakan IPB.

Tillman, A.D., H. Hartadi, S. Reksohadoprodjo, S. Prawirikusumo dan S. Lebdosoekojo. 1989. Ilmu Makanan Ternak dasar. Gadjah Mada University Press. Fakultas Peternakan UGM.

Widyawati, Susi, D. dan W.P.S. Suprayogi. 2006. Perbaikan Produktivitas Ternak Ruminansia pada Peternakan Rakyat Melalui Pemberian Growth Promoting Feed Supplement. Laporan Penelitian Hibah Pekerti Tahun I. Fakultas Pertanian UNS.

Widyobroto B.P., S. Padmowijoto, dan R. Utomo. 1997 Pendugaan kualitas protein 60 bahan pakan untuk ternak ruminansia. Laporan Penelitian. Fakultas Peternakan UGM, Yogyakarta.

Widyobroto BP., SPS. Budhi, A. Agus and B. Santosa. 1999. Effect of undegraded protein level on nutrient digestibility and microbial protein synthesis of dairy cows. In : Lobley GE, A. White and JC. MacRae. (Ed). Protein metabolism and nutrition. Book of abstracts of the VIIIth International Symposium on Protein and Metabolism. P. 72. EAAP publication Wageningen Holland.

Widyobroto B.P. 1999. Pengaruh Tipe Karbohidrat dan Aras Undegraded Protein terhadap Konsumsi, Kecernaan Nutrien dan Parameter Fermentasi Rumen Sapi Peranakan Friesian Holstein, Buletin Sintesis Nomor : 11 Tahun VII, Agustus 1999, Yayasan Dharma Agrika Semarang, Hal. 1-8. 